\title{
SYMPOSIUM
}

\section{requiem for a dream? academic career opportunities for young political scientists in germany ${ }^{1}$}

\section{achim goerres and andreas warntjen}

Government Department, London School of Economics and Political Science, London WC1N2AN, UK

Corresponding author: A.Goerres@lse.ac.uk

doi: $10.1057 /$ palgrave.eps. 2210085

\begin{abstract}
We describe the current career system for young political scientists in Germany academia. The situation is still dominated by the apprenticeship model in which young PhD graduates undertake a second supervised piece of research. Recently introduced junior professorships are still too few and far between to have a major impact and represent only a half-hearted effort. The current system is still unattractive, unproductive, and uncompetitive. A lecturer tenure-track system would shift insecurity to the beginning of a career and would have built-in incentives and resources for young political scientists to engage in high-quality research.
\end{abstract}

Keywords career opportunities; Germany; Habilitation; tenure track

$\mathrm{T}$

he higher education system in Germany is undergoing a major overhaul at the moment in an effort to increase its international competitiveness. Besides the introduction of a $\mathrm{BA} /$ MA structure for the first academic degree, the traditional career path of young academics is currently under scrutiny. The so-called 'apprenticeship model' for PhDs and young academics is being supplemented partially by a system that is in spirit closer to the Anglo-Saxon tenure-track model. However, whether or not the introduction of Juniorprofessuren is an improvement in the situation for young scholars is disputed. ${ }^{2}$ Furthermore, the changes only represent a half-hearted effort. There are still no permanent positions below full professor. Finally, even this reform has not been fully implemented throughout Germany. There are only few junior professorships for political science so far and whether or not this number will be increased substantially is unclear at the moment. The system of Habilitation and an entry age above forty for permanent positions still remain the norm.

After finishing a PhD, a young scholar in Germany faces the decision of whether to 
risk an academic career or not. A junior scholar, who is usually in his or her early thirties after the PhD, will have to consider long-term personal commitments at that point. Thus, starting an academic career remains a huge gamble which only the lucky, the rich or the natural born academics can afford. Add to this uncertainty inherent in the system the party political debates raging over its current reform and you get a picture of a profession that is currently very unattractive.

In our view, the current system of recruitment of junior scholars is one of the reasons why German political science is not as competitive at the international level as it could be. Some of the most qualified young academics might be discouraged from pursuing an academic career in Germany because of the relatively low salary, the late stage at which independent research can be carried out, and most importantly, the uncertainty involved in an academic career. A lecturer tenure-track system reduces this uncertainty because it offers a permanent position for potential academics at an early stage.

If Germany wants to offer a world-class research environment and training, the country will have to adopt the lecturer tenure-track system that is, for example, in place in the Netherlands (see Andersen, Haverland and Nölke, this volume), Denmark or the UK.

After characterising the potential entrants to the German academic job market in 'At the Crossroad's - Young Political Scientists in Germany, we will discuss the current academic career opportunities for young scholars of Germany in 'Prospects for an Academic Career, or: How to become A Professor?'. 'Evaluation of the Current German System' evaluates the implications of the German 'apprenticeship model' for junior researchers and the system as a whole. We conclude by pointing out the advantages of the lecturer system, in which material insecurity
'On completion of the $P h D$, a young political scientist in Germany is not so young anymore. In 2000, political scientists were on average 35 years when they received their PhD.'

only exists at the beginning of the career, and by assessing the likelihood of its implementation in Germany.

\section{AT THE CROSSROADS - YOUNG POLITICAL SCIENTISTS IN GERMANY}

Upon finishing their MA, political scientists trained in Germany were on average twenty-eight years old in 2003 (ISA, 2005). They can then decide to stay at university and pursue a PhD. ${ }^{3} \mathrm{~A} \mathrm{PhD}$ is an attractive option for graduates even if they do not wish to start an academic career. It increases your salaries: fifteen years after being awarded a PhD, German political scientists and sociologists earn forty per cent more than their peers without a PhD (Jurkuhn, 2002). Close to one fifth of political science students continue their studies at university to earn a PhD (Wissenschaftsrat, 2002; Table 4). This figure has been increasing recently due to the current difficulties of finding a job in Germany (Rasch, 2004).

The outside options that the nonacademic job market offers have an important effect on the recruitment of young academics. On completion of the $\mathrm{PhD}$, a young political scientist in Germany is not so young anymore. In 2000, political scientists were on average thirtyfive years when they received their $\mathrm{PhD}$ (Wissenschaftsrat, 2002; Table 1 ). ${ }^{4}$ Particularly in light of the rigidity of the German job market, their high age means 
that fresh PhD graduates have to make a careful decision about which path to take - academia or the professions.

The non-academic labour market for social scientists in general is tough, but far from being hopeless. Although the unemployment rate for political scientists has been slightly higher than the rate for all university graduates in recent years, it is still well below the overall unemployment rate (Zentralstelle für Arbeitsvermittlung, 2005, personal communication). Surveys of alumni of the political science faculties in Marburg and Cologne show that most graduates work for interest groups, political parties, or in the private sector, most prominently for the media but also in industry (Jahr et al, 2000; Thull, 2004). Unlike other countries, political scientists are not very prominent in the German civil service. The reason for this is that jobs are still mainly reserved for lawyers ('Juristenmonopo/), with economists running a distant second. Thirty-eight per cent of civil servants in the German foreign office, for example, studied law. Only 9 per cent graduated in political science (Auswärtiges Amt, 2005, personal communication). For other federal ministries this fraction is even lower. Although the nonacademic job market for political scientists requires initiative and additional skills as well as practical experience (Bundesagentur für Arbeit, 2003; see Thull, 2004: 32-35), graduates are not headed for unemployment. Thirty percent of the respondents in the Marburg survey, which covered the period 19932000, got a full-time position immediately after graduation for which the study of political science had some relevance. Another 20 percent got a similar position, but had further qualifications such as a PhD or additional job training. A more recent survey by the University of Cologne (Thull, 2004) confirms this picture. Seventy percent had a job 6 months after graduation (including some

\section{'The ultimate goal of any academic career is a (full) professorship. In Germany, this is even truer than elsewhere as the alternative is to be in your mid-forties, highly educated and unemployed.'}

who had one even before graduation). Eighty-eight percent of the respondents were satisfied with their decision to study political science in retrospective. Thus, there are real alternatives for political science graduates to staying in academia. However, the chances on the non-academic job market decrease with the age of applicants and the duration of employment in academia. The decision to stay in academia after a PhD cannot be easily reversed after a few years. After being awarded a PhD, young political scientists in Germany find themselves at the crossroads and have to decide whether or not to risk an academic career.

\section{PROSPECTS FOR AN ACADEMIC CAREER, OR: HOW TO BECOME A PROFESSOR?}

The ultimate goal of any academic career is a (full) professorship. In Germany, this is even truer than elsewhere as the alternative is to be in your mid-forties, highly educated and unemployed. No permanent positions exist below the level of professorship and temporary positions at universities can only be taken up to a maximum of twelve years (Section $57 \mathrm{~b}$ Hochschulrahmengesetz).

Becoming a full professor of political science normally has two formal require- 
ments: to have a PhD and Habilitation (numerically still the most dominant postdoctoral qualification) or to have successfully finished a junior professorship. However, the requirement of the Habiliation is sometimes relaxed if the competition for a professorship is less fierce. The Habilitation is a kind of second $\mathrm{PhD}$ that is often much longer than the first ('the second book', also nicknamed 'the tombstone'). The candidate has to have a formal supervisor who is a full professor. During the time of Habilitation, the candidate is formally associated with the supervisor's institution, most often as an academic assistant (wissenschaftliche/r Assistent/in) who teaches seminars in the realm of the supervisor and reports to the supervisor. This system is sometimes referred to as the 'apprenticeship model'. The reasoning behind it is that the subtleties of social science research can only be learnt by an apprentice working in a close relationship with an established master scholar.

The supervisor has a significant say in the selection of the candidate. The money for the Habilitation position either comes from the faculty or from an external grant brought in by the supervisor or - in rare instances - from a grant that the supervisee brings in him or herself. ${ }^{5}$ It is normally financed for four years with a possible extension for another year. Alternatively, young researchers can apply for grants to finance their own positions at the German Science Foundation (Deutsche Forschungsgemeinschaft) or some other foundations that finance four-year projects. They are, however, few in numbers. The German Science Foundation gave out an estimated 14 grants for political science postdocs in 2004 that might potentially include the Habilitation. ${ }^{6}$ The most generous of these grants is the Emmy-Noether programme. To our knowledge, only one of those is currently held by a political scientist.
This system means that junior political scientists in Germany are dependent upon a senior scholar until they get a full professorship. When junior scholars fulfil the formal requirements for applying for those positions they are already in their mid-forties. Given the adversarial stance of German employers towards ex-academics, this long period in academia implies that most of them are doomed to stay at university if they want to have a career conforming to their qualifications.

This pressure clashes with the low probability of getting a permanent position for which there is always fierce competition. Between 1997 and 2001, 43.1 applications were made on average for each job opening (Wissenschaftsrat, 2005; Annex 1, Table 10). In the late 1990s, each year about twenty-five junior scholars finished their Habilitation, but there were only four job openings for new professors (Wissenschaftsrat, 2005: Annex 1).

The Social Democratic-Green federal coalition government introduced the junior professorship in 2002 to remedy this situation. The idea was to introduce a position below that of full professors that would allow young scholars to engage in independent research at an early stage in their career, similarly to the lecturer tenure-track model. A Juniorprofessor is co-financed by the federal level when the post is first installed and gets a three-year contract that allows the postholder to conduct research independently. After three years, there is a review, the terms of which are often not clearly defined at the beginning (Wissenschaftsrat, 2005: 46; Holzinger forthcoming, Rössel et al., 2003). On successful completion of the review, the candidate gets another three years. There are hardly any positions available. The authors were aware of only seventeen in political science in 2005. ${ }^{7}$ The German Ministry stopped financing new positions in the same year (BMBF, 
2005). ${ }^{8}$ The reason for this lies in the political debate on the future of higher education in Germany. Education and research are competences of the German states (Länder), some of which opposed the introduction of junior professorships by the federal government, although all German states welcomed the concept of the junior professorship in principle. Some German states such as Bavaria and Baden-Würtemberg continue mainly offering the Habilitation, while others, like Lower Saxony, offer both. ${ }^{9}$

There are a few further possibilities for starting an academic career in Germany: a postdoc position at one of the extrauniversity institutions (for example, the Mannheimer Zentrum für Europäische Sozialforschung, the Max Planck Institute for the Study of Societies in Cologne or the Wissenschaftszentrum Berlin). Most of these positions, however, are linked to projects that are supervised by senior personnel. A Habilitation is possible in some circumstances. Again, these attractive although not permanent positions are rare.

The last possibility is to become a teaching fellow (Lehrbeauftragte/r). These temporary (and poorly paid) positions can be used for a short while to avoid a period of academic unemployment. Teaching fellows get semester contracts based on the number of hours that they teach, similarly to graduate teaching assistants in the UK for example. But the teaching fellow does not have an office or any institutional support for research. The high teaching load, which is necessary to make a living in these positions, makes research a distant prospect. Thus, this career option is ill-suited as a step towards a professorship.

Before 2002, it was not uncommon for academic personnel to live off annual contracts for years in order to receive civil servant status (Verratung) with a permanent contract later on. The new legislation limiting temporary employment to a maximum of twelve years means that these opportunities no longer exist.

A typical career path in the current system develops as follows (see Figure 1): successful graduates pursue their PhD at their home university and follow this up with a Habilitation with the same supervisor. Given the degree to which Habilitanden are dependent on their supervisors, leaving for a different university to work under an unknown supervisor carries a great risk. At the end of the Habilitation and the end of the contract, the graduates gain professorial experience by replacing existing professors who might be on leave, typically for a year, at a university somewhere in Germany. By then, the average candidate is in his or her late thirties. The alternative is to find work as a teaching fellow on a semester basis and a very low salary. The candidate now faces a short window of opportunity to gain a permanent position; otherwise he or she is in her mid-forties and at risk of being unemployed with little chances of entering the non-academic job market. This problem is evident in the cases of those academics with a Habilitation who teach for free (Hartung, 2003). If you continue teaching for free, you may at least call yourself private tutor (Privatdozent/in). This seems to enhance your chances of getting a professorship because it means that you are still affiliated to a university and can build up further teaching experience (see Knodt et al, 2004).

\section{EVALUATION OF THE CURRENT GERMAN SYSTEM}

We will evaluate the prospects of young scholars in the present German system by comparing them to lecturer systems that are in place, for instance, in the UK, the Netherlands and the Scandinavian coun- 
Professur (first permanent position)

Age at job offer (average): 42.6

\section{Waiting period (privatdozent)}

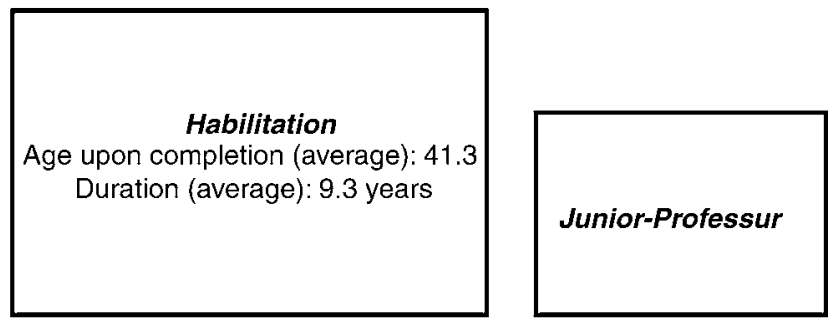

Doctoral Dissertation and Examination

Age upon completion (average): 33.5

Duration (average): 6.3 years

Graduation (MA)

Age upon completion (average): 28

Figure 1 The German Career System in Higher Education. Sources: Knodt et al., 2004, Wiesenschaftsrat, 2002, 2005.

tries (i.e. the lecturer tenure-track model). We will consider the consequences of both models for the junior scholar and the system as a whole.

The lecturer system offers a gradual transition into the profession by providing a first permanent position shortly (i.e. one to five years) after the $\mathrm{PhD}$, compared to a long waiting period of typically ten years in Germany (cf. Knodt et al, 2004). Normally, a PhD graduate can get a tenure-track lecturer position after a few years of postdoctoral experience. Entry salaries vary by country and can sometimes be low relative to non-academic positions requiring comparable qualifications.

We will not further consider postdoctoral possibilities at extra-university institutions in Germany because there are so few of them. Teaching fellowships are obviously unsuitable avenues for a future career, so we will discard them in our comparison as well.

\section{THE POSITION OF JUNIOR SCHOLAR}

The present system in Germany implies a high degree of dependence and uncertainty over a long period for junior scholars. The dependency of the supervisee on the Habilitation supervisor is striking. The supervisee suffers from a four-fold dependence on the supervisor: financially (as the supervisor is normally the direct boss of the Habilitand for teaching responsibilities and can, for instance, decline to support the extension of the contract), professionally (as the super- 
visor's network is important for the supervisee to make herself known in the German community), intellectually (as the supervisor is supposed to guide the Habilitand - who is typically in his or her early thirties at the outset) and finally with regard to the successful completion of the Habilitation (in this respect the candidate is also dependent on the whole faculty). In terms of independence, the junior professor is definitely better positioned vis-à-vis other faculty members, compared to someone doing a Habilitation. However, hazy evaluation criteria for the mid-term review (Holzinger forthcoming) and high teaching loads limit the independence of some junior professors. ${ }^{10}$

By contrast, in lecturer systems young scholars are dependent on other faculty members until they are through the review process (typically after three years). Clarity about review criteria (peer-reviewed publications, etc.) and a review decision by a committee rather than a single person further reduce dependence (and uncertainty).

Besides a lack of independence, the present German system puts its junior scholars in a position full of uncertainty. There is no financial security in terms of a steady income until you are a professor in the present German system. You typically spend a decade after your PhD moving from one temporary contract to another. This has severe repercussions for your life because it makes it harder to take on long-term commitments. The difficult situation is aggravated by the new limit of twelve years on temporary contracts.

In all academic systems, young scholars lose out financially by deciding for a career in academia. But if you are unsuccessful in a country with a lecturersystem, you have only 'wasted' three to five years of your life and can move on to another job. In Germany, you have to invest ten years to see whether or not you get anywhere and face a small window of
'If you are unsuccessful in a country with a lecturer system, you have only 'wasted' three to five years of your life and can move on to another job. In Germany, you have to invest ten years to see whether or not you get anywhere and face a small window of opportunity to obtain a permanent position.'

opportunity to obtain a permanent position. By then, it is hardly possible to pursue another career. This is a gamble which only the lucky, the rich or the natural born academics can afford.

The incentive structure in the German system is fundamentally different from the lecturer system. In the former, the tenured professorship is the junior scholar's only objective - it's all or nothing. The longer you are in, the higher your exit costs. The number of people with a Habilitation who work for free epitomises the oddity of the system. Contrast this to the tenure-track system, where young scholars gradually climb up the career ladder with a security net once they have passed the first stages (and then enjoy incentives to advance further).

\section{CONSEQUENCES FOR THE SYSTEM}

The German system does not represent a reliable framework for the best young scholars in political science to get to the top or produce good research on their way there. In two recent evaluations, German political science faculties fare badly (Plümper, 2003; Hix, 2004). Given 
their number (as approximated by population size), German faculties as a whole produce few articles in international journals compared to other European countries such as Norway, the Netherlands, Sweden or Switzerland (Plümper, 2003: 535).

One factor contributing to this is the difficult state of affairs for young researchers. Young researchers in Germany are driven hard if they decide to publish something in a peer-reviewed journal as it might not matter for their career advancement (see Holzinger forthcoming). The idea of the Habilitation as a highquality measure through which one can evaluate prospective professors misses the reality of international research. Scholars outside of Germany will not read a 700-1,000 pages book in German, albeit of high quality, but a twenty-page article in an international journal.

The lack of transparency and objective criteria in recruitment decisions and the alleged importance of personal networks give an incentive to engage in networking instead of pursuing original and innovative research that contributes to the international debate (see Holzinger, forthcoming). The long dependence on a more senior scholar also does not necessarily add to young scholars developing their own potential for new and path-breaking work.

The diversity across German regions (Länder) in terms of the requirements for a professorship is obsolete in a world of globalised competition for the best brains. In a world of cheap flights, you can be a lecturer in Hull or Odense and still see your parents in Dortmund over the weekend.

\section{CONCLUSIONS: TENURE- TRACK - A WAY FORWARD?}

Starting an academic career as a political scientist in Germany remains unattractive despite recent reforms. Graduating with a
PhD typically above the age of 30 years, young scholars are faced with the decision of leaving academia for good and capitalising on the value of a PhD in the professional job market or embarking on a voyage of uncertainty that lasts ten years or more and might end in a personal disaster. The relatively high age at $\mathrm{PhD}$ graduation and the long period of uncertainty increase opportunity costs immensely. In addition, young scholars who are willing to go further are faced with a lack of opportunities. If young scholars get one of the rare Habilitation positions, they have to deal with dependence on the supervisor in numerous ways and financial insecurity after the temporary position runs out. Thus, an academic career in German political science is not very attractive.

The negative consequences of the current recruitment system are far-reaching for German academia. Independent research output by young scholars is impaired because few young academics have long-term contracts that allow them to concentrate on research. This situation makes a brain drain of high-potential candidates and a lack of non-German political scientists coming to Germany more likely.

We think that a lecturer tenure-track system and $\mathrm{PhD}$ graduate schools are the way forward. ${ }^{11}$ Young scholars should face fierce, but fair competition twice: (a) to enter into a PhD programme that demands independent scientific inquiry and (b) to get a tenure-track lecturer position that includes a transparent, foreseeable review linked to the quality of research output and teaching (after three to five years) following which the position becomes permanent. This system shifts the insecurity to the beginning of the career when exit costs are low instead of keeping it up until they are unbearably high after a decade of insecure employment in academia. Established professors would 
benefit from such a system as well. The transformation of the German university system to BA and MA degrees means that the teaching load of full professors, which is already high in international comparison, is likely to rise even further. The introduction of lecturer positions could ease this burden. We should stress that a tenure-track system would only have the desired effects if tenured academics have further incentives to continue engaging in high-quality research.

The good news is that the state of German universities is now on the agenda of public discussions. The new Grand Coalition is in a good position to implement fundamental changes that require a consensus between Bund and Länder ('durchregieren'). Moreover, many German universities have discovered the financial opportunities of Master programmes to attract international students. Owing to the competitive pressures in this market, the demand rises for personnel with good credentials in research and teaching. Junior scholars with a long-term perspective would be ideally suited for such positions.

Unfortunately, there is another side to this coin. A lecturer system would - at least in the short-term - be more expensive because new positions must be financed on top of existing professorships. In times of severe federal and state deficits, a more expensive system is a difficult proposition for politicians to adopt.

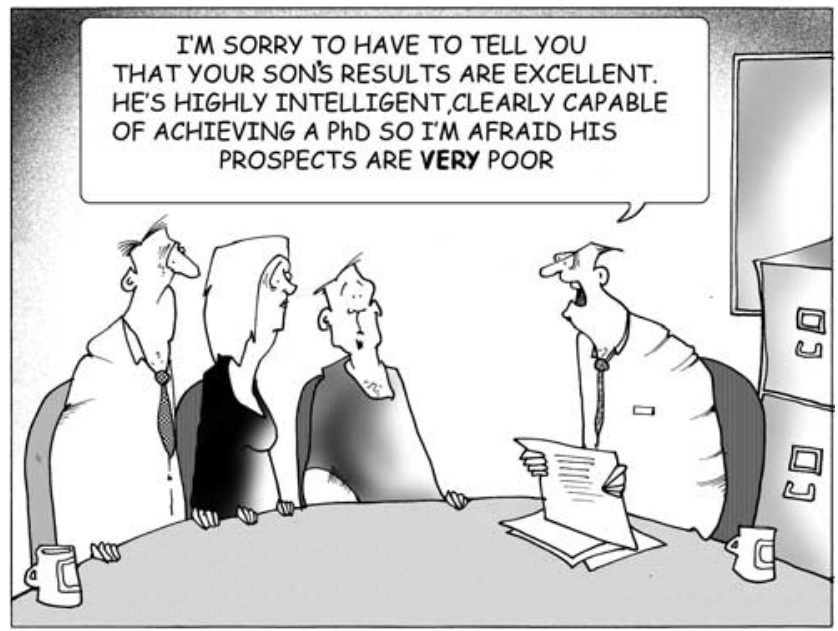

Fran@francartoons.com

\section{Notes}

1 The title is borrowed from Hubert Selby Jr.'s novel and the movie of the same name. We are very grateful to Anke Gerhardt and Thomas Plümper for making detailed results of their surveys available to us. We would also like to thank Andreas Busch, Gudrun Eisele, Peter Greisler, Thomas Gschwend, Ralf Kleinfeld, Sandra Pogodda, Torsten Selck, Kai Spiekermann, Stefanie Stegemann-Boehl, Joachim Wehner and Arndt Wonka for helpful comments.

2 Bahle (2002), for example, argues that the situation after the reforms is worse than before.

3 See Holzinger (forthcoming) for more details about the PhD stage.

4 A more recent survey by thesis e.V. (see Gerhardt et al, 2005) gives 31 as the average age at submission of the thesis (based on the estimates of the respondents). Knodt et al (2004) report 33.5 as the average age upon completion of the PhD after 1995.

5 Only recently, the German Science Foundation (DFG) opened funding applications for non-professors (DFG, 2004). 
6 The exact number of political scientists whose Habilitation is supported by the German Science Foundation cannot be traced (DFG, 2005, personal communication). However, in 2004, 41 research grants for postdocs were given out in the social sciences. Probably one third of those (maximum) were for political science (DFG, 2005, 95).

7 Free University Berlin, Bochum (2), Bremen, Dortmund, Erfurt, Frankfurt/Main, Frankfurt/Oder, Göttingen, Hamburg, Heidelberg, Jena, Kaiserslautern, Koblenz-Landau, Mannheim, Osnabrück, Trier.

8 The financial agreement between the German states and the federal government ran out at the end of 2004. Bavaria, Baden-Wuerttemberg and Hesse refused to accept a new agreement.

9 After a ruling by the German Constitutional Court in July 2004 because of illegal interference of the federal parliament with state competency in education and research, the legal basis of the junior professorship had to be revised (for an overview of regulations by the Länder see Wissenschaftsrat, 2005: Annex 2).

10 For a full evaluation of junior professorships see Rössel et al (2003).

11 This is not to say that any of the existing practices are perfect. In the UK, for example, young scholars on the job market are currently in a frenzy to get published before the deadline of the next Research Assessment Exercise, which determines future funding and thus decision about job applicants (Guardian, 2005). It is a safe bet that at least some of these papers would have profited from not having to meet an arbitrary de facto deadline for submission. For a more detailed comparison see Holzinger forthcoming.

\section{References}

Anderson, K., Haverland, M. and Nölke, A. (2006) 'Making a Political Science career in an Internationalised environment: a perspective from the Netherland', European Political Science 5(3):271-279.

Bahle, T. (2002) 'Eyes and ears wide shut. The reform of the university career structure in Germany', European Political Science 1(3): 4-11.

BMBF (2005) 'Juniorprofessur', available at http://www.bmbf.de/de/820.php,last accessed 29-11-05. Bundesagentur für Arbeit (2003) 'Arbeitsmarkt Politologen. Flexibilität zählt', Uni 3: 48-52.

DFG (2004) 'Merkblatt Forschungsstipendien', available at http://www.dfg.de/forschungsfoerderung/ formulare/download/1_04.pdf,last accessed 29-11-2005.

DFG (2005) Jahresbericht 2004. Aufgaben und Ergebnisse, Bonn: DFG.

Gerhardt, A., Briede, U. and Mues, C. (2005) 'Zur Situation der Doktoranden in Deutschland: Ergebnisse einer bundesweiten Doktorandenbefragung', Beiträge zur Hochschulforschung 27: 74-95.

Guardian (2005) 'Excrete or Die', available at http://education.guardian.co.uk/higher/research/story/ 0,9865,1660867,00.html,last accessed 27-1-2006.

Hartung, M. (2003) 'Lehre ohne Lohn', Die Zeit, 23 July.

Holzinger, K. (forthcoming) 'Career incentives', European Political Science.

Hix, S. (2004) 'European Universities in a Global Ranking of Political Science Departments', European Political Science 3(2): 5-23.

Informationssystem Studienwahl und Arbeitsmarkt (ISA) (2005) 'Sozialwissenschaften (Sozialwissenschaft/Soziologie) und Politikwissenschaften', available at http://www.uni-essen.de/ isa/fg_sozial_gesund/sozialwiss/sozialwiss_hs_frm.htm,last accessed 27-10-2005.

Jahr, V., Frechenhäuser, D., Büchner, T. and Galgon, T. (2000) 'Marburger PolitologInnen auf dem Arbeitsmarkt revisited: Die Jahrgänge 1993-2000', available at http://web.uni-marburg.de/ politikwissenschaft/archiv/absolventenbefragung_2000.html,last accessed 27-10-2005.

Jurkuhn, K. (2002) 'Der Preis von zwei Buchstaben', Die Süddeutsche, 2 February.

Knodt, M., Willems, U. and Kotzian, P. (2004) 'Karriereverläufe in der Politikwissenschaft', Politische Vierteljahresschrift 45(1): 109-115.

Plümper, T. (2003) 'Publikationstätigkeit und Rezeptionserfolg der deutschen Politikwissenschaft in internationalen Fachzeitschriften, 1990-2002. Eine bibliometrische Analyse der Veröffentlichungsleistung deutscher politikwissenschaftlicher Fachbereiche und Institute', Politische Vierteljahreszeitschrift 44(4): 530-570.

Rasch, C. (2004) 'Letzte Ausfahrt Promotion', taz, 10 April.

Rössel, J., Landfester, K. and Schollwöck, U. (2003) Die Juniorprofessur. Eine Bilanz ihrer Umsetzung, Berlin: Die Junge Akademie, available at http://www.diejungeakademie.de/publikationen/folder/ 435_Juniorprofessur_Abschlussbericht_0703.pdf, last accessed 15-01-2006.

Thull, E. (2004) 'Kölner Politikwissenschaftler und Politikwissenschaftlerinnen in Studium und Beruf. Ergebnisse einer Absolventenbefragung', ZA Information 55: 60-85, available at http://www.za. uni-koeln.de/publications/pdf/za_info/ZA-Info-55.pdf,last accessed 15-01-2006. 
Wissenschaftsrat (2002) 'Empfehlungen zur Doktorandenausbildung', available at http://www. wissenschaftsrat.de/texte/5459-02.pdf,last accessed 15-01-2006.

Wissenschaftsrat (2005) 'Entwicklung der Fachstudiendauer an Universitäten 1999-2003 - Anhang 1', available at http://www.wissenschaftsrat.de/texte/6825-05-1.pdf,last accessed 15 January 2006.

\section{About the Authors}

Achim Goerres is a PhD candidate at the London School of Economics and Political Science. His thesis and publications deal with political participation of older people across Europe. Further research interests include quantitative methods, comparative politics, and political behaviour.

Andreas Warntien is a PhD candidate at the London School of Economics and Political Science. His publications address topics related to interest aggregation in the EU; current research focuses on the impact of institutions on decision-making in the EU Council of Ministers. 